\title{
Ran GTPase-Activating Protein 1
}

National Cancer Institute

\section{Source}

National Cancer Institute. Ran GTPase-Activating Protein 1. NCI Thesaurus. Code C29762.

Ran GT Pase-activating protein 1 (587 aa, $\sim 64 \mathrm{kDa}$ ) is encoded by the human RANGAP1 gene. This protein is involved in the regulation of GTP-binding nuclear protein Ran signaling. 